\title{
Effect of ericoid mycorrhizal inoculants on the growth, development and healthiness of rhododendron variety Nova Zembla and Northern highbush blueberry variety Bluecrop
}

\author{
Wpływ szczepionek mikoryzowych dla wrzosowatych na wzrost, \\ rozwój i zdrowotność różanecznika odmiany Nova Zembla \\ oraz borówki amerykańskiej odmiany Bluecrop
}

\author{
Andrzej Księżniak ${ }^{1}$, Leszek B. Orlikowski ${ }^{2}$, Włodzimierz Szałański ${ }^{3}$, Barbara Wróblewska ${ }^{1}$
}

\begin{abstract}
Summary
The aim of this research was to study whether mycorrhizal fungi colonizing the roots of ericaceous plants may be regarded as a biocontrol agent against the Phytophthora cinnamomi pathogen. The pathogen's inoculum was mixed with the substrate 2 weeks after the planting rhododendron and blueberry plants. Five mycorrhizal inocula were prepared using the fungi isolated from roots of ericoid plants grown in natural habitat conditions. The observations on the growth and development of the rhododendron and blueberry plants were conducted 4, 8 and 12 weeks after the application of mycorrhizal inocula to the roots of tested plants. The research showed that both untreated and $P$. cinnamomi treated substrate, some of the tested inoculants stimulated the growth and number of leaves of tested plants, and reduced the degree of plant infection with the pathogen. The obtained results revealed the utility of used inocula to stimulate the development of ericaceous plants and reduce their infection with $P$. cinnamomi.
\end{abstract}

Key words: rhododendron, blueberry, biological control, mycorrhiza, Phytophthora cinnamomi

\section{Streszczenie}

Celem badań było sprawdzenie, czy grzyby mikoryzowe zasiedlające korzenie roślin wrzosowatych mogą być czynnikiem chroniącym je przed patogenem Phytophthora cinnamomi. Przeprowadzono badania skuteczności działania pięciu szczepionek mikoryzowych przygotowanych z udziałem grzybów wyizolowanych z korzeni roślin wrzosowatych rosnących w siedliskach naturalnych. Obserwacje wzrostu i rozwoju różanecznika i borówki amerykańskiej traktowanych wymienionymi szczepionkami przeprowadzono po 4, 8 i 12 tygodniach od aplikacji szczepionki mikoryzowej na korzenie roślin, których podłoża po 2 tygodniach od wysadzenia zakażano $P$. cinnamomi. Badania wykazały, że zarówno na podłożu niezakażonym, jak i zakażonym $P$. cinnamomi, niektóre z testowanych szczepionek stymulowały wzrost i liczbę liści badanych roślin oraz zmniejszały stopień porażenia roślin przez patogena. Stwarza to możliwość wykorzystania wybranych szczepionek do poprawy wzrostu i zdrowotności roślin wrzosowatych w warunkach narażenia na zakażenie $P$. cinnamomi.

Słowa kluczowe: różanecznik, borówka amerykańska, ochrona biologiczna, mikoryza, Phytophthora cinnamomi

\footnotetext{
${ }^{1}$ Instytut Uprawy Nawożenia i Gleboznawstwa - Państwowy Instytut Badawczy

Czartoryskich 8, 24-100 Puławy

aks@iung.pulawy.pl

${ }^{2}$ Instytut Ogrodnictwa

Pomologiczna 18, 96-100 Skierniewice

${ }^{3}$ Mykoflor', Rudy 84, 24-130 Końskowola
} 


\section{Wstęp / Introduction}

Chorobotwórcze dla roślin gatunki rodzaju Phytophthora mogą powodować znaczne straty w pojemnikowej produkcji szkółkarskiej roślin wrzosowatych (Orlikowski 1996; Orlikowski i wsp. 2010). W zależności od stopnia porażenia rośliny przez patogena, na częściach nadziemnych chorych roślin pojawiają się rdzawe nekrozy i uszkodzenia korzeni prowadzące do zmniejszenia plonu i jakości roślin ozdobnych, a nawet do zamierania całych roślin (Orlikowski 2006a). W celu ograniczania fytoftorozy roślin ozdobnych preferuje się uprawy odmian odpornych na chorobę, przestrzega odpowiednich procedur nawadniania i sterylizacji podłoży oraz wykorzystuje chemiczne i biologiczne metody ochrony roślin (Orlikowski 2006b). Z uwagi na rosnące ograniczenia w stosowaniu fungicydów, szczególną uwagę zwraca się na biologiczną ochronę z wykorzystaniem drobnoustrojów zasiedlających korzenie i strefę korzeniową roślin do zmniejszania porażenia roślin przez patogena. W celu wyeliminowania lub przynajmniej utrzymania populacji patogena poniżej progu ekonomicznej szkodliwości, mogą być również wykorzystane grzyby endofityczne i mikoryzy erikoidalnej, wyizolowane z korzeni roślin z mikoryzą. Grzyby te, zasiedlając korzenie roślin, stanowią konkurencję siedliskową i pokarmową dla patogenów, a także mogą wykazywać działanie antagonistyczne w stosunku do czynnika chorobotwórczego (Vigo i wsp. 2000; Księżniak i wsp. 2010). W efekcie powoduje to ograniczanie objawów chorobowych i poprawę wzrostu roślin mikoryzowanych w warunkach zagrożenia zakażeniem tych roślin przez Phytophthora cinnamomi.

Celem pracy było sprawdzenie przydatności grzybów wyizolowanych $\mathrm{z}$ korzeni roślin wrzosowatych w stymulowaniu ich wzrostu oraz jako środka ochrony roślin ograniczającego objawy fytoftorozy sadzonek roślin wysadzanych do podłoża torfowego zakażonego przez $P$. cinnamomi.

\section{Materiały i metody / Materials and methods}

Rośliny: Do doświadczenia wybrano borówkę amerykańską Bluecrop w stadium około 7 liści i średniej wysokości $35 \mathrm{~mm}$ oraz różanecznik Nova Zembla w stadium 8 liści i $32 \mathrm{~mm}$ wysokości. Posadzono je do doniczek 1-litrowych w substracie torfowym o $\mathrm{pH}=4,8$ po 5 sztuk w każdej $\mathrm{z}$ nich. Doświadczenie prowadzono w warunkach szklarniowych.

Szczepionki mikoryzowe: W doświadczeniach użyto szczepionki: VN-1, VN-2 i VN-3 uzyskane z korzeni borówki (Vaccinium sp.) oraz $\mathrm{CN}-1$ i CN-2 uzyskane z korzeni wrzosu (Calluna sp.). W zawiesinie tychże szczepionek moczono korzenie roślin bezpośrednio przed ich sadzeniem. Kontrolę stanowiły rośliny, których korzenie zanurzano tylko w wodzie.

Patogen: W doświadczeniu użyto $P$. cinnamomi, izolat z zamierającej podstawy różanecznika, jednego z najgroźniejszych patogenów roślin wrzosowatych (Orlikowski i Szkuta 2002). Inokulum tego gatunku przygotowano na płatkach owsianych zgodnie $\mathrm{z}$ metodyką podaną przez
Orlikowskiego (1999). Inokulum, w ilości $30 \mathrm{ml}$ naniesiono na powierzchnię podłoża jednej partii roślin, po 2 tygodniach od sadzenia roślin. Na drugiej partii roślin (kontrolnej) na powierzchnię dodano tylko po $30 \mathrm{ml}$ torfu na doniczkę.

Układ doświadczeń: Obejmowały one kombinacje z 5 szczepionkami oraz kontrolę bez szczepienia. Ponadto uwzględniono te same kombinacje, gdzie podłoże zakażano $P$. cinnamomi i nie zakażano. Doświadczenia założono w układzie bloków losowych w 4 powtórzeniach po 5 roślin w każdym z nich.

Pielęgnacja roślin: W ciągu 12-tygodniowej uprawy rośliny podlewano $\mathrm{W}$ miarę potrzeby oraz usuwano pojawiające się, pojedyncze chwasty. Dwukrotnie opryskano rośliny w celu zminimalizowania populacji przędziorka.

Obserwacje: Wykonano 4 obserwacje liczby liści na każdej z roślin oraz ich wysokości bezpośrednio po sadzeniu, a następnie w odstępach 4-tygodniowych.

Charakterystyka obliczeń statystycznych: istotność różnic pomiędzy średnimi wynikami pomiarów roślin w poszczególnych kombinacjach określano testem Duncana.

\section{Wyniki i dyskusja / Results and discussion}

Zastosowanie szczepionek w uprawie różanecznika spowodowało znacząco wyższe przyrosty wysokości roślin i liczby liści, zwłaszcza w przypadku użycia szczepionek VN-1 i VN-2 wyizolowanych z borówki (tab. 1). Wartości te utrzymywały się na wyższym poziomie również po 8 (tab. 2) i 12 tygodniach (tab. 3) uprawy różanecznika. W przypadku uprawy tych roślin na podłożu niezakażonym przez $P$. cinnammomi zaobserwowano większe przyrosty wysokości roślin, a także liczby liści na roślinie w porównaniu do wzrostu różanecznika na podłożu zakażonym patogenem. Z korzeni rododendronów izolowane są liczne szczepy grzybów erikoidalnych, które identyfikowane są przede wszystkim jako gatunki Oidiodendron maius oraz Hymenoscyphus ericae (Usuki i wsp. 2003). Szczepienie sadzonek rododendronów grzybami endofitycznymi wyizolowanymi $\mathrm{z}$ naturalnie zasiedlonych korzeni borówki (Vaccinium myrtillus) powodowało kolonizowanie korzeni rododendronów i nawiązywanie pseudomikoryzy, która jednak wykazywała obojętne oddziaływanie na wzrost tych roślin (Vohnik i wsp. 2003). Przeprowadzone doświadczenia z różanecznikiem wykazały natomiast pozytywne efekty wzrostowe po zastosowaniu szczepionek opartych na izolatach wyodrębnionych z korzeni borówki. W doświadczeniu ze szczepieniem borówki amerykańskiej uzyskano pozytywne wyniki w ciagu całego okresu wegetacji (tab. 4, 5, 6), przy czym istotne statystycznie efekty wystąpiły zarówno po zastosowaniu szczepionki VN-1 (izolaty z korzeni borówki), jak i CN-1 (izolaty z korzeni wrzosów). Ograniczeniem dla stosowania szczepionek mikoryzowych w ochronie roślin przed patogenami jest wolniejsze działanie $\mathrm{w}$ porównaniu do fungicydów i niecałkowite eliminowanie czynnika chorobotwórczego ze środowiska wzrostu rośliny. Z tego względu w przeprowadzonych doświadczeniach podłoże zakażano po dwóch tygodniach od mikoryzacji roślin $\mathrm{w}$ momencie sadzenia. Efekty 
Tabela 1. Wpływ szczepionek mikoryzowych na wzrost i rozwój różanecznika Nova Zembla po 4 tygodniach uprawy Table 1. Effect of mycorrhizal inocula on the growth of rhododendron Nova Zembla 4 weeks after planting

\begin{tabular}{l|c|c|c|c}
\hline \multirow{2}{*}{$\begin{array}{c}\text { Kombinacje } \\
\text { Treatments }\end{array}$} & \multicolumn{2}{c|}{$\begin{array}{c}\text { Wysokość roślin - Height of plants } \\
{[\mathrm{mm}]}\end{array}$} & $\begin{array}{c}\text { Liczba liści na roślinie } \\
\text { Number of plant leaves }\end{array}$ \\
\cline { 2 - 5 } & $\begin{array}{c}\text { podłoże niezakażone } \\
\text { substrate untreated }\end{array}$ & $\begin{array}{c}\text { podłoże zakażone } \\
\text { substrate treated } \\
\text { with P. cinnamomi }\end{array}$ & $\begin{array}{c}\text { podłoże niezakażone } \\
\text { substrate untreated }\end{array}$ & $\begin{array}{c}\text { podłoże zakażone } \\
\text { substrate treated } \\
\text { with P. cinnamomi }\end{array}$ \\
\hline Kontrola-Control & $52,8 \mathrm{de}$ & $42,4 \mathrm{ab}$ & $9,5 \mathrm{~cd}$ & $8,2 \mathrm{a}-\mathrm{c}$ \\
\hline $\begin{array}{l}\text { Szczepionka VN-1 } \\
\text { Inoculant VN-1 }\end{array}$ & $55,4 \mathrm{de}$ & $50,1 \mathrm{c}-\mathrm{e}$ & $11,0 \mathrm{de}$ & $10,0 \mathrm{c}-\mathrm{e}$ \\
\hline $\begin{array}{l}\text { Szczepionka VN-2 } \\
\text { Inoculant VN-2 }\end{array}$ & $57,2 \mathrm{e}$ & $48,7 \mathrm{~b}-\mathrm{d}$ & $11,9 \mathrm{e}$ & $9,7 \mathrm{~cd}$ \\
\hline $\begin{array}{l}\text { Szczepionka VN-3 } \\
\text { Inoculant VN-3 }\end{array}$ & $53,3 \mathrm{de}$ & $42,7 \mathrm{a}-\mathrm{c}$ & $10,1 \mathrm{c}-\mathrm{e}$ & $7,3 \mathrm{ab}$ \\
\hline $\begin{array}{l}\text { Szczepionka CN-1 } \\
\text { Inoculant CN-1 }\end{array}$ & $55,7 \mathrm{de}$ & $48,6 \mathrm{~b}-\mathrm{d}$ & $8,8 \mathrm{~b}-\mathrm{d}$ & $8,5 \mathrm{a}-\mathrm{c}$ \\
\hline $\begin{array}{l}\text { Szczepionka CN-2 } \\
\text { Inoculant CN-2 }\end{array}$ & $53,8 \mathrm{de}$ & $39,8 \mathrm{a}$ & $9,1 \mathrm{~b}-\mathrm{d}$ & $6,6 \mathrm{a}$
\end{tabular}

Średnie w kolumnach, oznaczone tą samą literą, nie różnią się (5\%) według testu Duncana - ocena różnic dla zakażonego i niezakażonego podłoża Average values in columns, marked with the same letter, do not differ significantly (5\%) according to Duncan's test - differences asessed for infested and non-infested substrate

Tabela 2. Wpływ szczepionek mikoryzowych na wzrost i rozwój różanecznika Nova Zembla po 8 tygodniach uprawy Table 2. Effect of mycorrhizal inocula on the growth of rhododendron Nova Zembla 8 weeks after planting

\begin{tabular}{l|c|c|c|c}
\hline \multirow{2}{*}{$\begin{array}{c}\text { Kombinacje } \\
\text { Treatments }\end{array}$} & $\begin{array}{c}\text { Wysokość roślin - Height of plants } \\
\text { [mm] }\end{array}$ & \multicolumn{2}{c}{$\begin{array}{c}\text { Liczba liści na roślinie } \\
\text { Number of plant leaves }\end{array}$} \\
\cline { 2 - 5 } & $\begin{array}{c}\text { podłoże niezakażone zakażone } \\
\text { substrate treated } \\
\text { with P. cinnamomi }\end{array}$ & $\begin{array}{c}\text { podłoże niezakażone } \\
\text { substrate untreated }\end{array}$ & $\begin{array}{c}\text { podłoże zakażone } \\
\text { substrate treated } \\
\text { with P. cinnamomi }\end{array}$ \\
\hline Kontrola - Control & $68,0 \mathrm{bc}$ & $57,5 \mathrm{a}$ & $10,2 \mathrm{bc}$ & $10,1 \mathrm{a}-\mathrm{c}$ \\
\hline $\begin{array}{l}\text { Szczepionka VN-1 } \\
\text { Inoculant VN-1 }\end{array}$ & $68,8 \mathrm{bc}$ & $62,8 \mathrm{ab}$ & $12,3 \mathrm{~cd}$ & $10,9 \mathrm{bc}$ \\
\hline $\begin{array}{l}\text { Szczepionka VN-2 } \\
\text { Inoculant VN-2 }\end{array}$ & $79,2 \mathrm{c}$ & $63,6 \mathrm{ab}$ & $13,3 \mathrm{~d}$ & $11,5 \mathrm{~cd}$ \\
\hline $\begin{array}{l}\text { Szczepionka VN-3 } \\
\text { Inoculant VN-3 }\end{array}$ & $65,4 \mathrm{a}-\mathrm{c}$ & $57,9 \mathrm{a}$ & $11,8 \mathrm{~cd}$ & $8,9 \mathrm{ab}$ \\
\hline $\begin{array}{l}\text { Szczepionka CN-1 } \\
\text { Inoculant CN-1 }\end{array}$ & $70,6 \mathrm{bc}$ & $58,4 \mathrm{a}$ & $10,8 \mathrm{bc}$ & $10,3 \mathrm{bc}$ \\
\hline $\begin{array}{l}\text { Szczepionka CN-2 } \\
\text { Inoculant CN-2 }\end{array}$ & $70,8 \mathrm{bc}$ & $56,6 \mathrm{a}$ & $11,9 \mathrm{~cd}$ & $8,1 \mathrm{a}$ \\
\hline
\end{tabular}

Średnie w kolumnach, oznaczone tą samą literą, nie różnią się (5\%) według testu Duncana - ocena różnic dla zakażonego i niezakażonego podłoża Average values in columns, marked with the same letter, do not differ significantly (5\%) according to Duncan's test - differences asessed for infested and non-infested substrate

Tabela 3. Wpływ szczepionek mikoryzowych na wzrost i rozwój różanecznika Nova Zembla po 12 tygodniach uprawy Table 3. Effect of mycorrhizal inocula on the growth of rhododendron Nova Zembla 12 weeks after planting

\begin{tabular}{|c|c|c|c|c|}
\hline \multirow{2}{*}{$\begin{array}{l}\text { Kombinacje } \\
\text { Treatments }\end{array}$} & \multicolumn{2}{|c|}{$\begin{array}{l}\text { Wysokość roślin }- \text { Height of plants } \\
{[\mathrm{mm}]}\end{array}$} & \multicolumn{2}{|c|}{$\begin{array}{l}\text { Liczba liści na roślinie } \\
\text { Number of plant leaves }\end{array}$} \\
\hline & $\begin{array}{l}\text { podłoże niezakażone } \\
\text { substrate untreated }\end{array}$ & $\begin{array}{c}\text { podłoże zakażone } \\
\text { substrate treated } \\
\text { with } P \text {. cinnamomi }\end{array}$ & $\begin{array}{l}\text { podłoże niezakażone } \\
\text { substrate untreated }\end{array}$ & $\begin{array}{c}\text { podłoże zakażone } \\
\text { substrate treated } \\
\text { with } P \text {. cinnamomi }\end{array}$ \\
\hline 1 & 2 & 3 & 4 & 5 \\
\hline Kontrola - Control & $72,4 \mathrm{c}-\mathrm{e}$ & $58,9 \mathrm{a}$ & $11,3 \mathrm{~b}-\mathrm{d}$ & $10,6 \mathrm{bc}$ \\
\hline $\begin{array}{l}\text { Szczepionka VN-1 } \\
\text { Inoculant VN-1 }\end{array}$ & $79,2 \mathrm{e}$ & $70,5 \mathrm{~b}-\mathrm{e}$ & $13,4 \mathrm{de}$ & $11,7 \mathrm{~b}-\mathrm{d}$ \\
\hline
\end{tabular}




\begin{tabular}{l|c|c|c|c}
\hline \multicolumn{1}{c|}{1} & 2 & 3 & 4 & 5 \\
\hline $\begin{array}{l}\text { Szczepionka VN-2 } \\
\text { Inoculant VN-2 }\end{array}$ & $78,9 \mathrm{e}$ & $70,6 \mathrm{~b}-\mathrm{e}$ & $13,8 \mathrm{e}$ & $11,8 \mathrm{c}-\mathrm{e}$ \\
\hline $\begin{array}{l}\text { Szczepionka VN-3 } \\
\text { Inoculant VN-3 }\end{array}$ & $75,3 \mathrm{de}$ & $64,6 \mathrm{a}-\mathrm{c}$ & $12,1 \mathrm{c}-\mathrm{e}$ & $9,6 \mathrm{ab}$ \\
\hline $\begin{array}{l}\text { Szczepionka CN-1 } \\
\text { Inoculant CN-1 }\end{array}$ & $75,7 \mathrm{de}$ & $67,3 \mathrm{a}-\mathrm{d}$ & $11,2 \mathrm{~b}-\mathrm{d}$ & $11,3 \mathrm{~b}-\mathrm{e}$ \\
\hline $\begin{array}{l}\text { Szczepionka CN-2 } \\
\text { Inoculant CN-2 }\end{array}$ & $75,7 \mathrm{de}$ & $61,7 \mathrm{ab}$ & $12,4 \mathrm{c}-\mathrm{e}$ & $8,3 \mathrm{a}$ \\
\hline
\end{tabular}

Średnie w kolumnach, oznaczone tą samą literą, nie różnią się (5\%) według testu Duncana - ocena różnic dla zakażonego i niezakażonego podłoża Average values in columns, marked with the same letter, do not differ significantly (5\%) according to Duncan's test - differences asessed for infested and non-infested substrate

Tabela 4. Wpływ szczepionek mikoryzowych na wzrost i rozwój borówki Bluecrop po 4 tygodniach uprawy

Table 4. Effect of mycorrhizal inocula on the growth of blueberry Bluecrop after 4 weeks

\begin{tabular}{|c|c|c|c|c|}
\hline \multirow{2}{*}{$\begin{array}{c}\text { Kombinacje } \\
\text { Treatments }\end{array}$} & \multicolumn{2}{|c|}{$\begin{array}{l}\text { Wysokość roślin - Height of plants } \\
{[\mathrm{mm}]}\end{array}$} & \multicolumn{2}{|c|}{$\begin{array}{l}\text { Liczba liści na roślinie } \\
\text { Number of plant leaves }\end{array}$} \\
\hline & $\begin{array}{l}\text { podłoże niezakażone } \\
\text { substrate untreated }\end{array}$ & $\begin{array}{l}\text { podłoże zakażone } \\
\text { substrate treated } \\
\text { with } P \text {. cinnamomi }\end{array}$ & $\begin{array}{l}\text { podłoże niezakażone } \\
\text { substrate untreated }\end{array}$ & $\begin{array}{l}\text { podłoże zakażone } \\
\text { substrate treated } \\
\text { with } P \text {. cinnamomi }\end{array}$ \\
\hline Kontrola - Control & $61,8 \mathrm{c}-\mathrm{e}$ & $68,0 \mathrm{~d}-\mathrm{g}$ & $8,3 \mathrm{a}-\mathrm{c}$ & $8,4 \mathrm{a}-\mathrm{c}$ \\
\hline $\begin{array}{l}\text { Szczepionka VN-1 } \\
\text { Inoculant VN-1 }\end{array}$ & $74,1 \mathrm{~g}$ & $52,7 \mathrm{ab}$ & $9,5 \mathrm{c}$ & $7,1 \mathrm{a}$ \\
\hline $\begin{array}{l}\text { Szczepionka VN-2 } \\
\text { Inoculant VN-2 }\end{array}$ & $64,1 \mathrm{c}-\mathrm{f}$ & $56,0 \mathrm{a}-\mathrm{c}$ & $8,1 \mathrm{a}-\mathrm{c}$ & $7,7 \mathrm{ab}$ \\
\hline $\begin{array}{l}\text { Szczepionka VN-3 } \\
\text { Inoculant VN-3 }\end{array}$ & $59,7 \mathrm{~b}-\mathrm{d}$ & $50,2 \mathrm{a}$ & $9,3 \mathrm{bc}$ & $7,3 \mathrm{a}$ \\
\hline $\begin{array}{l}\text { Szczepionka CN-1 } \\
\text { Inoculant } \mathrm{CN}-1\end{array}$ & $71,7 \mathrm{fg}$ & $48,7 \mathrm{a}$ & $9,6 \mathrm{c}$ & $7,3 \mathrm{a}$ \\
\hline $\begin{array}{l}\text { Szczepionka CN-2 } \\
\text { Inoculant } \mathrm{CN}-2\end{array}$ & $69,6 \mathrm{e}-\mathrm{g}$ & $52,6 \mathrm{ab}$ & $9,4 \mathrm{c}$ & $8,3 \mathrm{a}-\mathrm{c}$ \\
\hline
\end{tabular}

Średnie w kolumnach, oznaczone tą samą literą, nie różnią się $(5 \%)$ według testu Duncana - ocena różnic dla zakażonego i niezakażonego podłoża Average values in columns, marked with the same letter, do not differ significantly (5\%) according to Duncan's test - differences asessed for infested and non-infested substrate

Tabela 5. Wpływ szczepionek mikoryzowych na wzrost i rozwój borówki Bluecrop po 8 tygodniach uprawy Table 5. Effect of mycorrhizal inocula on the growth of blueberry Bluecrop after 8 weeks

\begin{tabular}{l|c|c|c|c}
\hline \multirow{2}{*}{$\begin{array}{c}\text { Kombinacje } \\
\text { Treatments }\end{array}$} & \multicolumn{2}{|c|}{$\begin{array}{c}\text { Wysokość roślin - Height of plants } \\
\text { [mm] }\end{array}$} & \multicolumn{2}{c}{$\begin{array}{c}\text { Liczba liści na roślinie } \\
\text { Number of plant leaves }\end{array}$} \\
\cline { 2 - 5 } & $\begin{array}{c}\text { podłoże zakażone } \\
\text { substrate treated } \\
\text { with P. cinnamomi }\end{array}$ & $\begin{array}{c}\text { podłoże niezakażone } \\
\text { substrate untreated }\end{array}$ & $\begin{array}{c}\text { podłoże zakażone } \\
\text { substrate treated } \\
\text { with P. cinnamomi }\end{array}$ \\
\hline Kontrola - Control & $78,4 \mathrm{a}-\mathrm{c}$ & $83,6 \mathrm{bc}$ & $13,3 \mathrm{~cd}$ & $11,2 \mathrm{a}-\mathrm{c}$ \\
\hline $\begin{array}{l}\text { Szczepionka VN-1 } \\
\text { Inoculant VN-1 }\end{array}$ & $88,5 \mathrm{c}$ & $82,1 \mathrm{a}-\mathrm{c}$ & $14,6 \mathrm{~d}$ & $9,8 \mathrm{a}$ \\
\hline $\begin{array}{l}\text { Szczepionka VN-2 } \\
\text { Inoculant VN-2 }\end{array}$ & $77,8 \mathrm{a}-\mathrm{c}$ & $77,2 \mathrm{a}-\mathrm{c}$ & $12,8 \mathrm{~b}-\mathrm{d}$ & $9,9 \mathrm{a}$ \\
\hline $\begin{array}{l}\text { Szczepionka VN-3 } \\
\text { Inoculant VN-3 }\end{array}$ & $89,0 \mathrm{c}$ & $77,9 \mathrm{a}-\mathrm{c}$ & $14,6 \mathrm{~d}$ & $10,2 \mathrm{ab}$ \\
\hline $\begin{array}{l}\text { Szczepionka CN-1 } \\
\text { Inoculant CN-1 }\end{array}$ & $85,7 \mathrm{bc}$ & $72,0 \mathrm{ab}$ & $13,8 \mathrm{~cd}$ & $9,7 \mathrm{a}$ \\
\hline $\begin{array}{l}\text { Szczepionka CN-2 } \\
\text { Inoculant CN-2 }\end{array}$ & $85,7 \mathrm{bc}$ & $68,7 \mathrm{a}$ & $15,1 \mathrm{~d}$ & $11,3 \mathrm{a}-\mathrm{c}$ \\
\hline
\end{tabular}

Średnie w kolumnach, oznaczone tą samą literą, nie różnią się (5\%) według testu Duncana - ocena różnic dla zakażonego i niezakażonego podłoża Average values in columns, marked with the same letter, do not differ significantly $(5 \%)$ according to Duncan's test - differences asessed for infested and non-infested substrate 
Tabela 6. Wpływ szczepionek mikoryzowych na wzrost i rozwój borówki Bluecrop po 12 tygodniach uprawy

Table 6. Effect of mycorrhizal inocula on the growth of blueberry Bluecrop after 12 weeks

\begin{tabular}{l|c|c|c|c}
\hline \multirow{2}{*}{$\begin{array}{c}\text { Kombinacje } \\
\text { Treatments }\end{array}$} & \multicolumn{2}{c|}{$\begin{array}{c}\text { Wysokość roślin - Height of plants } \\
{[\mathrm{mm}]}\end{array}$} & $\begin{array}{c}\text { Liczba liści na roślinie } \\
\text { Number of plant leaves }\end{array}$ \\
\cline { 2 - 5 } & $\begin{array}{c}\text { substrate untreated } \\
\text { podłoże zakażone } \\
\text { substrate treated } \\
\text { with P. cinnamomi }\end{array}$ & $\begin{array}{c}\text { podłoże niezakażone } \\
\text { substrate untreated }\end{array}$ & $\begin{array}{c}\text { podłoże zakażone } \\
\text { substrate treated } \\
\text { with P. cinnamomi }\end{array}$ \\
\hline Kontrola-Control & $102,2 \mathrm{~b}-\mathrm{e}$ & $89,7 \mathrm{a}-\mathrm{d}$ & $17,0 \mathrm{~b}$ & $14,0 \mathrm{a}$ \\
\hline $\begin{array}{l}\text { Szczepionka VN-1 } \\
\text { Inoculant VN-1 }\end{array}$ & $113,4 \mathrm{e}$ & $90,0 \mathrm{a}-\mathrm{d}$ & $17,7 \mathrm{~b}$ & $13,5 \mathrm{a}$ \\
\hline $\begin{array}{l}\text { Szczepionka VN-2 } \\
\text { Inoculant VN-2 }\end{array}$ & $101,4 \mathrm{c}-\mathrm{e}$ & $86,7 \mathrm{a}-\mathrm{c}$ & $17,5 \mathrm{~b}$ & $13,9 \mathrm{a}$ \\
\hline $\begin{array}{l}\text { Szczepionka VN-3 } \\
\text { Inoculant VN-3 }\end{array}$ & $102,5 \mathrm{c}-\mathrm{e}$ & $84,1 \mathrm{ab}$ & $17,6 \mathrm{~b}$ & $13,3 \mathrm{a}$ \\
\hline $\begin{array}{l}\text { Szczepionka CN-1 } \\
\text { Inoculant CN-1 }\end{array}$ & $99,5 \mathrm{~b}-\mathrm{e}$ & $77,0 \mathrm{a}$ & $16,8 \mathrm{~b}$ & $12,8 \mathrm{a}$ \\
\hline $\begin{array}{l}\text { Szczepionka CN-2 } \\
\text { Inoculant CN-2 }\end{array}$ & $105,0 \mathrm{de}$ & $82,2 \mathrm{a}$ & $18,4 \mathrm{~b}$ & $14,1 \mathrm{a}$
\end{tabular}

Średnie w kolumnach, oznaczone tą samą literą, nie różnią się (5\%) według testu Duncana - ocena różnic dla zakażonego i niezakażonego podłoża Average values in columns, marked with the same letter, do not differ significantly (5\%) according to Duncan's test - differences asessed for infested and non-infested substrate

Tabela 7. Wpływ szczepionek mikoryzowych na zdrowotność wrzosów i borówki; liczba porażonych roślin $(\mathrm{n}=5)$ po 8 tygodniach uprawy

Table 7. Effect of mycorrhizal inocula on the healthiness of rhododendrons and blueberry; number of plant with Phytophthora rot $(\mathrm{n}=5)$ after 8 weeks of growth

\begin{tabular}{l|c|c|c|c}
\hline \multirow{2}{*}{$\begin{array}{c}\text { Kombinacje } \\
\text { Treatments }\end{array}$} & \multicolumn{2}{|c|}{$\begin{array}{c}\text { Różanecznik Nova Zembla } \\
\text { Rhododendron Nova Zembla }\end{array}$} & $\begin{array}{c}\text { Borówka Bluecrop } \\
\text { Blueberry Bluecrop }\end{array}$ \\
\cline { 2 - 5 } & $\begin{array}{c}\text { podłoże niezakażone } \\
\text { substrate untreated }\end{array}$ & $\begin{array}{c}\text { podłoże zakażone } \\
\text { substrate treated } \\
\text { with P. cinnamomi }\end{array}$ & $\begin{array}{c}\text { podłoże niezakażone } \\
\text { substrate untreated }\end{array}$ & $\begin{array}{c}\text { podłoże zakażone } \\
\text { substrate treated } \\
\text { with P. cinnamomi }\end{array}$ \\
\hline Kontrola - Control & $0 \mathrm{a}$ & $0,8 \mathrm{a}$ & $0,1 \mathrm{ab}$ & $0,7 \mathrm{~b}$ \\
\hline $\begin{array}{l}\text { Szczepionka VN-1 } \\
\text { Inoculant VN-1 }\end{array}$ & $0 \mathrm{a}$ & $0,5 \mathrm{a}$ & $0 \mathrm{a}$ & $0,4 \mathrm{ab}$ \\
\hline $\begin{array}{l}\text { Szczepionka VN-2 } \\
\text { Inoculant VN-2 }\end{array}$ & $0 \mathrm{a}$ & $0,5 \mathrm{a}$ & $0 \mathrm{a}$ & $0,1 \mathrm{ab}$ \\
\hline $\begin{array}{l}\text { Szczepionka VN-3 } \\
\text { Inoculant VN-3 }\end{array}$ & $0,3 \mathrm{a}$ & $0 \mathrm{a}$ & $0 \mathrm{a}$ & $0,1 \mathrm{ab}$ \\
\hline $\begin{array}{l}\text { Szczepionka CN-1 } \\
\text { Inoculant CN-1 }\end{array}$ & $0,3 \mathrm{a}$ & $1,0 \mathrm{a}$ & $0 \mathrm{a}$ & $0,3 \mathrm{ab}$ \\
\hline $\begin{array}{l}\text { Szczepionka CN-2 } \\
\text { Inoculant CN-2 }\end{array}$ & $0,3 \mathrm{a}$ & $1,0 \mathrm{a}$ & $0 \mathrm{a}$ & $0,1 \mathrm{ab}$ \\
\hline
\end{tabular}

Średnie w kolumnach, oznaczone tą samą litera, nie różnią się (5\%) według testu Duncana - ocena różnic dla zakażonego i niezakażonego podłoża Average values in columns, marked with the same letter, do not differ significantly (5\%) according to Duncan's test - differences asessed for infested and non-infested substrate

wzrostowe i ochronne (tab. 7) uzyskane w przypadku szczepienia różaneczników i borówki amerykańskiej wskazują, że ich aplikacja może być uzasadniona po dobraniu najbardziej efektywnych izolatów. Nie jest wykluczone, że skuteczność ochronna szczepionki mikoryzowej przed $P$. cinnamomi byłaby wyższa przy równoczesnym wykorzystaniu kilku izolatów grzybów mikoryzowych i być może przy wykorzystaniu antagonistycznych wobec $P$. cinnamomi bakterii, co w wielu przypadkach daje lepsze efekty ochrony, niż gdy stosowane są szczepionki jednoskładnikowe (Whipps 2001).

\section{Wnioski / Conclusions}

1. Z przeprowadzonych badań wynika, że poszczególne szczepionki powodowały zróżnicowane reakcje badanych roślin różanecznika i borówki amerykańskiej.

2. Różanecznik odmiany Nova Zembla lepiej reagował wzrostowo na szczepionki oparte na izolatach grzybowych uzyskanych z korzeni borówki (VN).

3. Borówka amerykańska w podłożu zakażonym przez P. cinnamomi rosła lepiej $\mathrm{w}$ obecności szczepionki 
opartej na izolatach grzybowych uzyskanych z korzeni wrzosu $(\mathrm{CN})$.

4. Zaobserwowano lepsze efekty ograniczania fytoftorozy borówki amerykańskiej po zastosowaniu szczepionek
VN i CN, w porównaniu do ochrony różanecznika, gdzie skuteczniejsza była szczepionka VN.

5. Wcześniejsza mikoryzacja sadzonek roślin różanecznika i borówki może poprawiać ich wzrost i ograniczać stopień porażenia przez patogena $P$. cinnamomi.

\section{Literatura / References}

Księżniak A., Wróblewska B., Szałański W. 2010. Wpływ szczepionek mikoryzowych na rozwój i zdrowotność różaneczników i wrzosów. Zesz. Probl. Post. Nauk Rol. 554: 65-70.

Orlikowski L.B. 1996. Phytophthora species in Polish ornamental nurseries. II. Chemical and biological control of P. cinnamomi on Chamaecyparis lawsoniana cv. Ellwoodi. Phytopathol. Pol. 11: 111-120.

Orlikowski L.B. 1999. Selective medium for the evaluation of biocontrol agents efficacy in the control of soilborne pathogens. Bull. Pol. Pol. Acad. Sci., Biol. Sci. 47: 167-172.

Orlikowski L.B. 2006a. Gatunki rodzaju Phytophthora jako czynniki ograniczające plon i jakość roślin ozdobnych. Zesz. Probl. Post. Nauk Rol. 510: 407-411.

Orlikowski L.B. 2006b. Ochrona roślin ozdobnych w szkółkach pojemnikowych przed fytoftorozą. Prog. Plant Prot./Post. Ochr. Roślin 46 (1): 358-365.

Orlikowski L.B., Ptaszek M. 2010. Narastające problemy występowania chorób w pojemnikowej produkcji roślin ozdobnych. Prog. Plant Prot./Post. Ochr. Roślin 50 (2): 678-686.

Orlikowski L.B., Szkuta G. 2002. Occurrence of Phytophthora cinnamomi on ericaceous plants in container-grown ornamental nurseries in Poland. J. Plant Prot. Res. 42 (2): 157-163.

Usuki F., Abe J.P., Kakishima M. 2003. Diversity of ericoid mycorrhizal fungi isolated from hair roots of Rhododendron obtusum var. kaempferi in a Japanese red pine forest. Mycoscience 44 (2): 0097-0102.

Vigo C., Norman J.R., Hooker J.E. 2000. Biocontrol of the pathogen Phytophthora parasitica by arbuscular mycorrhizal fungi is a consequence of effects on infection loci. Plant Pathol. 49 (4): 509-514.

Vohnik M., Lukancic S., Bahor E., Regvar M., Vosatka M., Vodnik D. 2003. Inoculation of Rhododendron cv. Belle-Heller with two strains of Phialocephala fortini in two different substrates. Folia Geobotanica 38 (2): 191-200.

Whipps J.M. 2001. Microbial interactions and biocontrol in the rhizosphere. J. Exp. Bot. 52: 487-511. 